\title{
Agency heads say sorry to board for criticism from staff
}

Sydney. In a new twist to the troubled relations between scientific staff and top managers at Australia's largest research agency, the Commonwealth Scientific and Industrial Research Organisation (CSIRO), the heads of the agency's five major research divisions have apparently written to apologize for criticisms by their staffs of the CSIRO board.

The letters, which were subsequently read out to the staff of the five divisions, were written after a meeting between Roy Green, acting chief executive of CSIRO, and the heads of units based around the national capital, Canberra.

None of the unit heads - nor Green would comment last week on what happened at the meeting, which had been held to discuss a submission to the board signed by most of the Canberra staff after a management report suggesting various structural changes had been circulated for comment (see Nature 374, 587; 1995).

The staff document complained of a "widespread lack of confidence" in both the board and a committee it had set up to produce the management report. But after discussing its strong wording with Green and another board member, the division heads all agreed to send letters that those who heard them read out say amounted to apologies.

According to one CSIRO scientist, the main source of contention was not the remark about a lack of confidence but a separate accusation that board members had a "conflict of interest". The staff had intended this merely as a comment on the fact that board members are part-time - only the acting chief executive officer is full-time and hold posts outside the organization, not that there is any monetary conflict.

Green later denied that the letter was an apology, but said that the wording in the submission did not appear to convey the message that the staff had wished to communicate to the board. He said that the division chiefs had acknowledged that point — and had so informed their staff.

Both Green and Adrienne Clarke, chair of the CSIRO board and professor of botany at Melbourne University, say they accept that the present staff difficulties stem from failures of internal communication. Another widely cited problem is the amount of time taken up with administrative requirements and frequent reviews of research.

Green is now setting up a committee to examine such issues. At the same time, he denies having ignored the report of a previous Senate committee of inquiry on CSIRO, and says that it was taken into account during the writing of CSIRO's own management report.

Mark Lawson

\section{Coalition plans challenge to genetic patenting in the US}

San Francisco. Scientists, clergy and activists will meet in the Adirondack mountains next week to discuss how to stimulate a broad public debate in the United States about the moral and ethical aspects of patenting human genes and living organisms.

The meeting, which will also be attended by representatives of agricultural, native American and health advocacy groups, comes on the heels of a well-publicized appeal by a broad-based coalition of more than 175 religious leaders to stop the patenting of genetically engineered animals and human genes, cells and organs.

The statement received front-page coverage in newspapers across the United States. It brings together a number of weighty political constituencies that often find themselves on opposite sides of issues such as abortion and school prayers.

The campaign has been largely organized by Jeremy Rifkin, director of the Foundation on Economic Trends in Washington, and a long-time opponent of genetic engineering. The signatories say that they are not concerned about the biotechnology industry itself. But they voiced strong disagreement with attempts by scientists and corporations to "grab" what they consider rightfully belongs to humanity.

"We have to consider [the human genome] to be a natural resource," said Abdurahman Alamoudi, executive director of the American Muslim Council in Washington. "It's like the water, the wind; it doesn't belong to anybody."

Biotechnology industry leaders have responded by arguing that patents are essential for the development of modern medicines, and by drawing a distinction between the legal protection conferred by patenting and actual ownership.

But members of the Council for Responsible Genetics, which is organizing next week's meeting, say that patents on living organisms may impede medical progress by effectively 'privatizing' publicly funded research and limiting the free exchange of scientific information.

Richard Levins, John Rock professor of population science at the Harvard School of Public Health, called gene patenting a means of "subordinating a common intellectual heritage for private gain". He and other scientists say that the traditional collegial exchange of ideas in laboratories is being replaced by a concern for protecting potential monetary gains.

Philip L. Bereano, professor of public policy at the University of Washington and an organizer of next week's meeting, says that the decision by religious leaders to take up the issue is likely to help awaken the American public to the debate.

The religious leaders themselves said last week that they hope the US Patent and Trademark Office will suspend the issuing of new patents. They plan to begin discussions with their own members, and to put pressure on Congress to take action.

Americans have ceded decisions on issues raised by biotechnology to commercial and scientific interests, said Rabbi Daniel Swartz, director of congregational relations at the Religious Action Center in Washington. He said religious leaders can put the

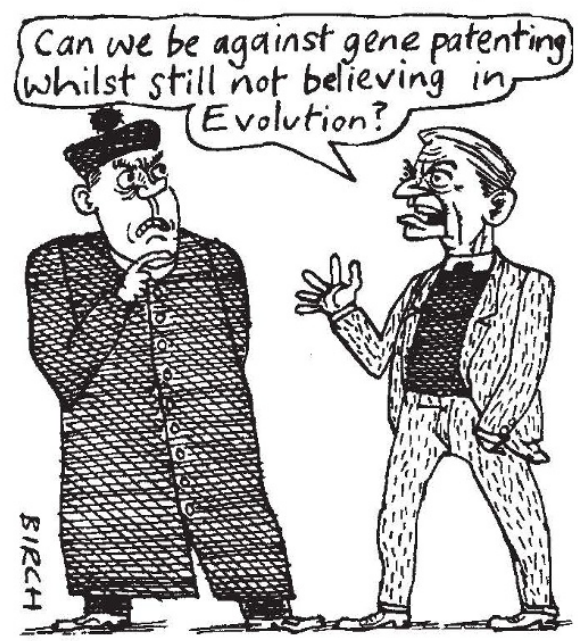

gene patents in the context of the broader devaluation of life in modern society.

But many scientists feel that the clergy's petition reflects either a lack of understanding of the patent system or a bias against biotechnology in general. David Galas, for example, vice president of research and development for Darwin Molecular Corporation in Seattle, says the call for a moratorium is far too sweeping and could crush the financial incentive behind the industry.

Galas, who opposes patenting of gene sequences whose function is unknown, points out that patents are designed as a way of simultaneously placing information in the public domain, and rewarding the inventor.

Rebecca Eisenberg, professor of law at the University of Michigan law school and an adviser to the National Institutes of Health on patent issues, acknowledges that biotechnology patents raise important issues. But she says that Rifkin's group poses the question in a sensationalist and provocative manner.

Instead, says Eisenberg, the public should be looking at the impact of the current proliferation of patents on basic research, and whether patenting the early stages of a technical development retards later commercial development.

Sally Lehrman 